\title{
Odkud se berou \\ Dětská pojetí oběhu peněz
}

\author{
Michaela Dvořáková
}

\begin{abstract}
Abstrakt: Studie uvádi do problematiky vývoje dètských pojeti ekonomických vztahì, konkrétnè oběhu penèz v obdobi primárního vzdèláváni. Představuje teoretický rámec výzkumu dètských pojetí a prèdkládá dosavadni výzkumná zjištèní. Cílem bylo ve vztahu k teoretickému rámci ziskat a interpretovat vlastni výzkumná data $k$ dètským pojetím obèhu penèz a porovnat výsledky s podobně zamérenými zahraničnimi výzkumy z poslednich 30 let. Metoda-Data byla ziskána z polostrukturovaných rozhovorü zaměrených na dètská pojetí obèhu penèz. Transkripty rozhovorú byly kódovány a dètská pojeti následně kategorizována podle míry jejich komplexnosti a kompatibility dílčich myšlenek. Výsledky - V obou částech výzkumu dètská pojetí vykazuji tendenci aplikovat na ekonomickou sféru vlastni sociálni zkušenost. Oborovè specifická pojetí odkazujici k predstavě trhu práce nebo oběhu penèz ve společnosti byla vázána na zkušenost žáka s prací rodiču nebo na jiné konkrétni príklady více než na věk dotazovaných. Závèry - Elicitovaná pojeti trhu práce a obèhu penèz mohou prispèt oborové didaktice společenských vèd jako východisko pro proces konceptuálni zmèny. Výsledky nabizeji varianty neúplných, chybných konceptù nebo ukazuji na jejich absenci a dávaji podnèty pro iniciaci konceptuálni zmèny ve výuce.
\end{abstract}

Kličová slova: dètská pojetí, konceptuálni zmèna, hloubkové rozhovory, primární vzdèláváni, obèh penèz, finančni gramotnost.

\section{ÚvoD}

Současné posílení témat finančního vzdělávání v kurikulu základního vzdělávání je součástí snahy o zvyšování finanční gramotnosti v ČR. Ekonomická témata jsou prŕḱkladem učiva, které je považováno za významné pro praktický život, srovnávací výzkumy poukazují na nedostatky ve finanční gramotnosti jak u českých žáků základních škol, tak u dospělé populace (Hradil, 2012). Zvyšování finanční gramotnosti je současnou vzdělávací politikou podporováno. Zatímco témata finančního vzdělávání jsou tradičně součástí kurikula výchovy k občanství, vybraná témata jsou od roku 2013 zařazena také do kurikula primární školy ve vzdělávací oblasti Člověk a jeho svět. Rozvoj finanční gramotnosti je podporován koncepčně standardy finančního vzdělávání, obsahově propracovaným kurikulem a v neposlední řadě i dostupnými příklady dobré praxe (Hesová, 2014; Klínský \& Chromá, 
2009). Veškerá podpora finančního vzdělávání se ale týká sekundárního vzdělávání. Učební texty $\mathrm{k}$ finančnímu vzdělávání na primární škole bývají redukovanou variantou textů pro 2. stupeň $Z \check{S}$, nerespektují kognitivní charakteristiky žáků, a tak nemohou být učitelům pro výuku potřebným vodítkem.

Předpokladem didaktického prŕstupu $\mathrm{v}$ intencích pedagogického konstruktivismu, ze kterého vycházíme, je zohlednění dosavadních porozumění, zájmů a otázek žáků. V textu užíváme souhrnné označení dětská pojetí, představující komplexní chápání určitého fenoménu, které ještě nemusí být verbálně vyjádřené. Vycházíme z doporučení Doulíka (2005), který považuje pojem dětská pojetí za nadřazený dalším označením používaným v literatuře, např. prekonceptům, miskonceptům. Termín dětské představy pak chápeme jako součást vybavování těchto pojetí (Škoda, 2005).

Naše práce by měla přispívat $\mathrm{k}$ didaktickému uchopení témat finančního vzdělávání v primárním vzdělávání, a to lepší orientací v dosavadních zkušenostech žáků a z nich vyvozovaných pojetí. Výzkumu dětských pojetí v oblasti společenských věd není v českém pedagogickém výzkumu věnována systematická pozornost, tato studie by měla alespoň v dílčích otázkách doplnění tohoto deficitu pomoci.

\section{VÝCHODISKA}

Východiskem našeho výzkumu jsou př́stupy pedagogického konstruktivismu $s$ jeho charakteristickým požadavkem zaměrení pozornosti na žáka, na jeho perspektivu a na proces poznávání. Pro svou práci považujeme za významný koncept „pedagogical content knowledge“ L. Shulmana, který do našich podmínek přináší Janík (2007), podobně jako model didaktické znalosti obsahu (Jelemenska, Sander \& Kattmann, 2003).

Těžiště zájmu výzkumníků sledujících dětská pojetí je tradičně situováno do matematiky a př́rodních věd. Výzkumy dětských pojetí z oblasti společenských věd mají výrazně menší rozsah, práce za posledních dvacet let 20. století, kdy bylo téma zkoumáno nejintenzivněji, jsou shrnuty v publikaci Children's understanding of society (Barrett \& Buchanan-Barrow, 2004).

Ve srovnání s ostatními společenskými vědami je dětským pojetím ekonomických vztahů věnováno nejvíce pozornosti. Máme $\mathrm{k}$ dispozici výsledky řady národních i mezinárodních výzkumů, prováděných $\mathrm{z}$ různých pedagogických a psychologických východisek. Zajímavou otázkou, kterou si položili autoři mezinárodního srovnávacího výzkumu v devadesátých letech 20. století, byla míra shody a odlišnosti pojetí dětí ze zemí bývalého socialistického bloku a zemí s tradicí tržního hospodářství. Přestože výzkumů s cílem porovnat ekonomické myšlení dětí ze států $s$ rozdílnou historickou zkušeností proběhlo v tomto období několik, Česká republika se žádného $\mathrm{z}$ nich neúčastnila. Za postkomunistické státy střední Evropy se zapojilo Polsko a Mad'arsko. Jediným zdrojem informací k ekonomic- 
kému myšlení dětí v českém prostředí jsou práce Vyskočilové, obsahově navazující na výzkumy F. Jiránka ze 70. let. Vyskočilová na konci 90. let provedla výzkum a následné srovnání s daty z Portugalska (Vyskočilová \& Morgado, 2000). Výsledky Vyskočilové podobně jako mezinárodní výzkum Leisera (Leiser \& Halachmi, 2006) naznačují, že děti z postsocialistických států projevovaly ve svých odpovědích tendenci přeceňovat vliv státu na ekonomiku.

\subsection{Historie výzkumu dětských pojetí funkce peněz a tržních vztahů}

Vycházíme z výzkumů ekonomického myšlení dětí z perspektivy pedagogického konstruktivismu. Z počátku byly výzkumy vedené explicitně $\mathrm{v}$ piagetovském kognitivně vývojovém pojetí. Již od padesátých let 20. století publikovali Schuessler a Strauss (1950, citováno dle Webley, 2004) studie vývoje porozumění významu peněz u dětí od předškolního věku. Podle piagetovského vývojového prýstupu definovali úrovně, skrze které děti procházejí (Webley, 2004). Na těchto studiích stavěla v osmdesátých letech dvojice Bertiová a Bombiová. Badatelky pokračovaly v piagetovském pojetí, ale předchozí studie dále rozpracovaly, zkoumaly u dětí předškolního a mladšího školního věku porozumění způsobu používání peněz při nakupování a prodávání a dále zjištovaly dětské představy o zdrojích peněz (Berti, 2002).

Výzkumy $\mathrm{v}$ piagetovské vývojové tradici byly kritizovány za své zaměření na vývoj operačního myšlení, zatímco konkrétní projevy dětských pojetí zde měly pouze funkci instrumentu použitého k identifikování kvalitativně odlišných úrovní myšlení (Berti, Bombi \& Duveen, 1988; Berti, 2002; Siegler \& Thompson, 1998). Siegler a Thompson (tamtéž) ukazují na klíčový posun v průběhu 90. let ve výzkumech dětských pojetí od obecně vývojových $\mathrm{k}$ doménově specifickým. Výzkumy vycházející z doménově specifické perspektivy se věnují systematičtějšímu mapování dětských pojetí uvnitř jednotlivých oborů, v oblasti ekonomického myšlení je to zejména porozumění tržním vztahům. Názorným př́kladem oborově specificky vedeného výzkumu pro ekonomii je rozsáhlý výzkum porozumění aspektům tvorby cen (Leiser, Seven \& Daphna, 1990; Siegler \& Thompson, 1998; Bonn \& Webley, 2000; Brophy, Alleman \& Halvorsen, 2018; Marton \& Pang 2008).

Obecně vývojové východisko výzkumu bývá kritizováno také z pozic sociokognitivní perspektivy pro jakési „zprůměrované" dětské pojetí, které nebere ohled na vliv socioekonomického a kulturního zázemí dětí (Hutchings, 2002). Uniformitu vývojového pohledu překonávají výzkumy z Jihoafrické republiky (Bonn \& Webley, 2000), ze Spojených států (Parsons \& Mamo, 2017), z České republiky a Portugalska (Vyskočilová \& Morgado, 2000). K dosud nejrozsáhlejším srovnávacím výzkumům porozumění tržním vztahům patři výzkum Leisera (Leiser \& Halachmi, 2006), který shromáždil výsledky z deseti zemí. Našemu prostředí by mohlo 
být blízké zjištění polských a mad’arských výzkumníků, že děti z původně centrálně řízených socialistických ekonomik chápaly záměr podnikatelů vytvářet zisk hưře a později než děti ze států $s$ volným trhem (tamtéž).

Dosud provedené srovnávací studie ukázaly, že mezi výsledky národních výzkumů jsou rozdíly, které jsou ale pravděpodobně mnohem méně významné než rozdíly působené věkem (Webley, 2004). Výzkumy dětských pojetí, ze kterých vycházíme, jsou staršího data, protože novější práce zkoumající dětská pojetí sociální reality jsou realizovány v rámci teorie konceptuální změny (Clement, 2000; Chi, 2013; di Sessa, 2013; Vosniadou, 2013; Davies, 2019).

\subsection{Dosavadní výzkumná zjištění k dětským pojetím funkce peněz a tržních vztahů}

$\mathrm{V}$ předchozích kapitolách jsme se zabývali psychodidaktickými východisky realizovaných výzkumů dětských pojetí. $\mathrm{V}$ této části se zaměríme na obsah výzkumných zjištění ohledně dětských pojetí ekonomického fungování společnosti, konkrétněji představ o oběhu peněz.

Dosavadní zjištění dvojice Bertiová a Bombiová (1988) ohledně zdrojů peněz naznačují změnu pojetí $\mathrm{v}$ závislosti na věku. $Z$ jejich analýzy vyplývají čtyři kategorie. Na úrovni 1 zhruba od 4-5 let věku děti nemají pojem o původu peněz. $\mathrm{Na} 2$. úrovni vidí děti původ peněz nezávisle na práci, např́klad banky je dávají těm, kdo si řeknou. $\mathrm{Na} 3$. úrovni si děti myslely, že peníze pocházejí z výměny mezi prodávajícím a kupujícím při nákupu zboží. Na úrovni 4 zhruba kolem 7. roku si děti spojovaly peníze $s$ prací, prohlašovaly, že peníze přináší pouze práce (tamtéž). Tyto výsledky jsou v souladu s tradicí kognitivního vývoje. Ukazují na úseky vývoje, stadia, kterými děti procházejí $\mathrm{k}$ dosažení dospělého porozumění. Problematičnost prímočarého vývoje $\mathrm{k}$ dospělému porozumění je zřejmá $\mathrm{z}$ výzkumu pojetí fungování trhu u studentů na začátku vysokoškolského studia na regionálních univerzitách v USA (Parsons \& Mamo, 2017). Výzkum odhalil minimální oborové znalosti a velmi silná osobní přesvědčení studentů. V návaznosti na piagetovská východiska byla zjištěná pojetí interpretována jako systém předsudků, který má potenciál ovlivnit další učení.

Oproti tomu výzkumy oborově specifického proudu Leisera et al. (1990) a Webleyho (2004) při hledání faktorů ovlivňujících pojetí respondentů považují za významný sociální kontext a vlastní zkušenosti, oproti čistě vývojovému hledisku (Bastounis, Leiser \& Roland-Levy, 2008). Leiser et al. (1990) poukazují na to, že bez chápání vztahů mezi prací a zdrojem peněz mívají žáci představu o firmách jako o charitativních institucích, které svým zaměstnancům poskytují sociální zabezpečení. Tyto představy byly v mezinárodním výzkumu 1990 zřetelně identifikovány $\mathrm{u}$ respondentů $\mathrm{z}$ bývalé Jugoslávie a Tuniska. Dosavadní výzkumy pojetí fungování trhu (Jahoda, 1983; Berti \& Bombi, 1988; Leiser et al., 1990) 
ukazují, že klíčovým pojmem k porozumění fungování trhu je zisk. Teprve když žáci dokáží odložit morální kritéria př̀i posuzování fungování trhu, nahlédnou na proces obchodování z pohledu nakupujícího, prodávajícího i výrobce a přijmou možnost vytvářet zisk jako legitimní, mohou rozvíjet svou cenovou, a tím i celkově finanční gramotnost.

Funkce tohoto pojmu ve smyslu změny perspektivy je blízká teorii tzv. treshold concepts (Davies, 2019), které vedou ke kvalitativně odlišnému pohledu na obsah předmětu. Klíčovým úkolem oborově specifického výzkumu je identifikace pojmů $s$ tímto potenciálem, $\mathrm{v}$ ekonomii byly jako treshold concepts označeny např. pojmy nabídka - poptávka (tamtéž). Vzhledem k tomu, že treshold concepts jsou identifikovány jako prahové pojmy při budování vědeckého rámce disciplín, byly zkoumány zejména u studentů vyššího sekundárního a terciárního stupně. Výzkum pojmů, které vedou $\mathrm{k}$ transformaci pojetí u mladších žáků, je prováděn $\mathrm{v}$ rámci teorie konceptuální změny, zaměřené na pohyb od každodenních zkušeností k oborovému myšlení.

\subsection{Teorie konceptuální změny}

Teorie konceptuální změny navazuje na Piageta $v$ předpokladu, že poznatky nelze předat, ale žák si je musí vystavět zevnitř. Společným znakem zastánců teorie konceptuální změny však je důraz na doménově specifické zkoumání vývoje dětského myšlení. Na rozdíl od piagetovského směřování $\mathrm{k}$ obecným etapám dětského myšlení se tedy u teorie konceptuální změny předpokládá, že vývoj poznávání různých oblastí reality může postupovat odlišným tempem a má své specifické problémy.

Chiová (2013, s. 49) rozlišuje v závislosti na míre a uspořádání předchozích znalostí různé procesy učení:

1. Pokud žáci nemají žádné předchozí zkušenosti nebo znalosti k pojmům, které jsou předmětem výuky, učení spočívá v získávání nových znalostí.

2. Žáci mají správné, ale pouze dílčí znalosti, učením se zaplňují mezery. $\mathrm{V}$ případech chybějících nebo nekompletních pojetí se učení odehrává skrze obohacování stávajících poznatkových struktur.

3. Žák má $\mathrm{k}$ vyučovanému tématu vědomosti odvozené $\mathrm{z}$ vlastní zkušenosti nebo z předchozího vzdělávání, ty jsou ale $\mathrm{v}$ rozporu s koncepty, které jsou vyučovány. Získávání poznatků se v tomto př́padě děje prostřednictvím konceptuální změny. Třetí varianta procesu učení je předmětem zkoumání $\mathrm{v}$ rámci paradigmatu konceptuální změny.

Pro zkoumání procesu konceptuální změny je podle Chiové (2013, s. 50) nutné položit si tyto otázky: Jak nesprávná jsou dětská pojetí? Proč jsou špatně pochopené znalosti často rezistentní? Co způsobuje změnu v pojetí? Jaký postup výuky bude konceptuální změnu podporovat?

Odpovědi na tyto otázky se u různých výzkumníků liší, přesto je možné sledovat dva hlavní směry, které se liší v otázce soudržnosti poznatkové struktury. Zásadní rozdíl je možné shrnout následujícími otázkami: Je možné dětská pojetí popsat 
jako soudržný rámec podobný vědeckým teoriím (Vosniadou, 2013), anebo je výstižnější žákovy poznatky považovat za ekosystém volně propojených prvků (di Sessa, 2013)?

Ve výzkumné literatuře historicky převažuje perspektiva poznatků jako soudržných teorií. Výzkumníky této perspektivy výrazněji ovlivnila Piagetova teorie učení, k objasnění konceptuálního posunu použili analogie s Piagetovými pojmy asimilace a akomodace. Oproti piagetovské tradici se ale zaměřují na výzkum mechanismů proměny konceptů. Pojem koncept ve výzkumu konceptuální změny často označuje širši škálu mentálních objektů či jevů než jen izolované a statické koncepty. Chiová (2008) rozlišuje miskoncepty podle „zrnitosti“ na jednotlivé myšlenky, chybné mentální modely a systémy kategorizace. $\mathrm{Na}$ úrovni těchto „zrnitostí “ popisuje možnosti navození kognitivního konfliktu, který by měl umožnit konceptuální změnu.

Dủležitým príspěvkem $\mathrm{v}$ rámci této perspektivy je práce Careyové (1988), která popisuje pojetí dospělých a dětí jako každé samo o sobě koherentní, ale vzájemně nesouměřitelné. Změn mezi pojetími může být dosaženo třemi procesy: nahrazením (výměnou), odlišením a srůstáním. Careyová prezentuje svůj pohled na dětská pojetí na př́kladech z biologie. Uvádí, že konceptuální změna nemůže být chápána jako globální restrukturalizace ve smyslu Piagetově. Změnu pojetí považuje spíše za doménově specifické restrukturalizace. Jak jsou děti vystaveny novým zkušenostem a vyučování, pozvolna nahrazují své konceptuální struktury vědecky správnými konceptuálními strukturami. Tyto restrukturalizace jsou výsledkem nárůstu dětských znalostí v doméně, sociálních interakcí a různých zpochybňujících vlivů, které narušují dosavadní rovnováhu, částečně jsou také výsledkem vývoje logických struktur u dětí (tamtéž).

Výše uvedené teorie získaly širší podporu zejména $\mathrm{v}$ komunitě odborníků na didaktiku př́rodovědných předmětů, později se objevila konkurenční perspektiva, která charakterizuje žákovo poznávání ve smyslu „organického“ narůstání mnoha volně propojených elementů bez zastřešující struktury. Clark a di Sessa obhajující tuto organickou perspektivu se zaměrují na zkoumání procesu shromažd’ování elementů poznání, které obsahují fakta, příběhy, koncepty a mentální modely $\mathrm{v}$ různých stadiích vývoje a sofistikovanosti (Özdemir \& Clark, 2007; di Sessa, 2013). Výzkum z této perspektivy vidí konceptuální změnu jako evoluční revizi a reorganizaci. Zároveň připouští možnost koexistence protichůdných názorů $\mathrm{v}$ rámci poznatkového ekosystému jedince. Perspektiva ekosystému volně provázaných elementů připouští skrze dílčí elementy větší vliv kontextu poznávání.

Obě perspektivy se shodnou na tom, že konceptuální poznávání je velmi ovlivněno každodenní zkušeností s fenomény a událostmi. Jejich pojetí často zahrnují vysvětlení založená na vlastních zkušenostech, která mohou být $\mathrm{v}$ rozporu s normativním vědeckým vysvětlením. Naivní poznatky jsou východiskem kauzálních vysvětlení, která ovlivňují i pozdější formální (školní) 
učení, přestože jsou často nekompatibilní s obsahem školního kurikula odpovídajícího vědecké normě. Ke školní výuce normativních vědeckých teorií a konceptů musíme tedy vědět, jak žáci myslí, abychom mohli výuku žákům přizpůsobit. Mnoho naivních koncepcí je vysoce rezistentních ke změně. Proto je konceptuální změna proces, který potřebuje čas.

Náš přehled výzkumu v kapitole 2.1 naznačuje, že v posledních 20 letech byl shromážděn dostatek dat $\mathrm{k}$ dětským pojetím klíčových ekonomických pojmů. Dosud ale nebyl věnován dostatek pozornosti procesu změny těchto pojmů. Výjimkou jsou autoři Marton a Pang, kteří založili fenomenografickou výzkumnou tradici. $\mathrm{Ti}$ zaměrují svou pozornost od jednotlivých pojetí ke konceptuálním strukturám a označují jako typický pro rozvíjení struktury v dané oblasti posun od omezených pojetí získaných na základě osobní zkušenosti k pojetím, která umistují ekonomické fenomény do kontextu systémových interakcí, v nichž prríčina není jednosměrná ani jednoduše lineární (Marton $\&$ Pang, 2008).

$\mathrm{Z}$ toho důvodu jsme se rozhodli zaměřit svůj výzkum na zjištování komplexnosti a koherence dětských pojetí týkajících se oběhu peněz spíše než na diagnostiku pojetí dílčích jevů.

\section{Metodologie VÝZKUMU}

\subsection{Výzkumné otázky}

$\mathrm{V}$ rovině oborově didaktické je hlavní výzkumnou otázkou: Jaká jsou dětská pojetí oběhu peněz? Vedlejší výzkumné otázky zjištují dětské představy o původu peněz $\mathrm{v}$ rodinném rozpočtu a o původu peněz v bankách.

Vedlejší otázky jsme v průběhu výzkumu doplňovali a upřesňovali. Dotazování po původu peněz $\mathrm{v}$ rodině jsme se rozhodli doplnit otázkami o původu peněz v institucích, které žáci uváděli jako zdroj. Další otázky směřovaly $\mathrm{k}$ detekování představ o propojení těchto institucí a dále $\mathrm{k}$ mechanismům, podle kterých se peníze distribuují. $\mathrm{V}$ návaznosti na získané odpovědi jsme zjištovali, jak si žáci vysvětlují rozdílnou výši př́ijmů v různých profesích.

Vobsahovémzaměřeníotázekjsmeseinspirovali výzkumy Leisera a Halachmiové (2006), podle kterých žáci potřebují rozumět způsobu, jak se peníze vydělávají, aby si zřetelněji uvědomili různé zájmy účastníků trhu. Porozumění fungování trhu je pak předpokladem finančního vzdělávání.

$\mathrm{V}$ rovině obecně didaktické sledujeme míru komplexnosti dětských pojetí a koherenci vysvětlení dílčích jevů. Chceme tak přispět $\mathrm{k}$ diskusi nad mírou konzistence nebo rozporuplnosti dětských pojetí $\mathrm{v}$ rámci teorie konceptuální změny.

\subsection{Výzkumný plán}

Pro zjištování dětských pojetí oběhu peněz jsme zvolili hloubkové rozhovory s částečně zadanou strukturou (Clement, 2000). $\mathrm{K}$ vedení rozhovorů jsme vytvořili strukturu ve smyslu „lešení“, která měla zmenšovat rozdíly při získávání dat $\mathrm{v}$ závislosti 
na odborné připravenosti tazatelů (tamtéž). Tazateli byli studenti 4. ročníku studia učitelství prvního stupně ZŠ, kteří byli uvedeni do problematiky diagnostiky dětských porozumění a proškoleni $\mathrm{v}$ metodologii vedení hloubkových rozhovorů, zejména ve způsobu pokládání doplňujících otázek. Jejich úkolem bylo $\mathrm{v}$ individuálně vedeném rozhovoru položit otázky, zadat úlohy a zaznamenávat odpovědi žáků, řešení i jejich myšlení nahlas. $\mathrm{V}$ závislosti na odpovědi žáků formulovali doplňující otázky, které by přibližily žákovu cestu k odpovědi. Počet otázek a délka rozhovoru byly individuální v závislosti na ochotě dotazovaného a rozvinutosti jeho představ ke zkoumaným tématům. Průběžně jsme vyhodnocovali prínos výpovědí a pokračovali v šetření do nasycení vzorku.

\subsection{Výzkumný soubor}

Rozhovory byly vedeny se žáky 2 . až 5. ročníku. Respondenty tazatelé získávali mezi žáky primární školy na celém území ČR na základě dostupnosti, a to zejména podle možnosti získat souhlas rodičů $\mathrm{k}$ vedení rozhovoru. Socioekonomické zázemí žáků charakterizujeme částečně zaměstnáním rodičů, tyto charakteristiky bereme v úvahu při interpretaci odpovědí. Záznamy rozhovorů byly průběžně zpracovávány, aby bylo možné sledovat míru nasycení vzorku.

Nasycení vzorku v dotazování zaměřeném na komplexnost představ oběhu peněz bylo identifikováno při dosažení počtu 40 rozhovorů, z nichž 20 respondentů bylo ve věkovém rozmezí mezi 7 a 9 lety a 20 ve věkovém rozmezí mezi 10 a 11 lety. Další rozhovory již nebyly do studie zahrnuty, protože jejich výsledky nepřinášely nové pohledy ani neměnily proporce dosavadních zjištění.

$\mathrm{V}$ následném dotazování zaměřeném na dětská vysvětlení rozdílné výše příjmů u různých profesí bylo možné sledovat nasycení vzorku při zpracování 20 přepisů rozhovorů s respondenty ve věkovém rozmezí 9-11 let.

\subsection{Získávání a analýza dat}

Pro vytvoření struktury hloubkových rozhovorů jsme identifikovali témata a situace, skrze které by bylo možné dětská pojetí oběhu peněz otevř́it. Obsah dotazování jsme zaměřili na zjištování představ žáků o původu peněz pro jejich rodinu a sledování možných propojení zdrojů peněz do systému jejich oběhu. Při výběru otázek polostrukturovaného rozhovoru jsme se inspirovali vývojově orientovanými výzkumy (Berti, 2002) i výzkumy sociokognitivního směru (Jahoda, 1983; Leiser et al., 1990; Leiser \& Drori, 2005). Dalším důvodem pro volbu tématu byl předpoklad, že pracovní výkon rodičů v zaměstnání je dětem známý, a že proto bude $\mathrm{v}$ rozhovoru možné určité představy o tom, jak rodiče vydělávají peníze, detekovat. Podle našeho předpokladu mohlo toto téma plnit funkci propojovacího článku mezi dětskými představami a ekonomickým fungováním reálného světa.

$\mathrm{V}$ rámci pilotního ověřování jsme zjištovali srozumitelnost a potenciál otázek, které budou dětská pojetí elicitovat. 
Vzhledem k tomu, že dotazování směřovalo $\mathrm{k}$ porozumění situacím blízkým životu, nebyl zde problém se srozumitelností otázek, ale s jejich potenciálem zachytit dětská pojetí. V pilotních rozhovorech jsme se setkali se snahou dotazovaných odpovědět rychle, krátce a „správně“. Získané odpovědi měly velmi nízký potenciál, proto jsme provedli úpravy podmínek vedení rozhovorů a struktury otázek. Tazatele jsme připravili na vedení neformálních rozhovorů $\mathrm{v}$ uvolněné atmosféře. $\mathrm{Z}$ toho důvodu jsme vyloučili prostředí školní třídy nebo kabinetů učitelů a směrovali tazatele $\mathrm{k}$ vedení rozhovorů $\mathrm{v}$ rámci činnosti školní družiny a mimoškolních aktivit žáků. Výhodou studentů učitelství v roli tazatelů byla relativní věková blízkost a schopnost $\mathrm{v}$ rámci seznámení navázat $s$ dotazovaným vztah. Druhou úpravou byl návrh následných otázek, které pomáhaly odpovědi dále rozvíjet. $\mathrm{Na}$ ukázkách transkriptů pilotních rozhovorů jsme možnosti jejich použití demonstrovali a snažili jsme se na konkrétní problémy při vedení rozhovorů tazatele připravit. Ti odpovědi v průběhu rozhovorů zapisovali a zároveň pořizovali zvukový záznam. Zvukový záznam byl použit pro doplnění a upřesnění přepisu rozhovorů.

Po částečném zpracování odpovědí $\mathrm{k}$ původu peněz jsme identifikovali jako málo prozkoumané představy o práci rodičů. Zde se úplně nepotvrdil náš předpoklad, častou odpovědí bylo obecné konstatování o zaměstnání, kam rodiče chodí, bez ohledu na pracovní náplň nebo způsob financování. Proto jsme se rozhod- li realizovat další dotazování zaměřené na konkrétní príklady lépe a hưře placených profesí a dětská zdůvodnění těchto rozdílů, zároveň jsme sledovali, zda některá pojetí naznačují existenci trhu jako mechanismu, který výši př́ijmů ovlivňuje. Rozhovory byly vedeny a průběžně zpracovávány, dokud odpovědi přinášely nová zjišstění.

Transkripty rozhovorů byly zpracovány kvalitativně. Odpovědi jsme analyzovali $\mathrm{z}$ hlediska jejich obsahu a s využitím programu MAXQDA jsme je kódovali. Kategorie původně vycházely z obsahového zaměření otázek, odpovědi byly dále členěny do podkategorií, které vypovídají o míre komplexnosti a kompatibility dílčích myšlenek. Kategorizační systém byl v průběhu vyhodnocování výsledků upravován.

\section{VÝSLEDKY A JEJICH \\ INTERPRETACE}

\subsection{Zdroj peněz pro rodinu}

Odpovědi 40 dotazovaných jsme kódovali a na základě kódů kategorizovali do čtyř skupin A-D. Jednotlivé skupiny odpovědí jsou dále charakterizovány a u každé skupiny je prezentována ukázka typických výpovědí.

Př́i otázce na zdroj peněz pro rodinu většina respondentů odpověděla, že rodiče mají peníze z práce, kde je dostávají. Př́i dalším doptávání po původu peněz „, práci“ byly identifikovány více nebo méně elaborované odpovědi, které jsou zahrnuty do následujících kategorií. 


\section{A - Žádná organizace - „práce“ sama o sobě}

Původ peněz v práci uváděli všichni dotazovaní, většina $z$ nich svoji představu o tom, jak se peníze v práci vydělávají, dále specifikovala. Sedm dotazovaných ale ani na základě následných otázek žádné zdůvodnění neuvedlo.

Př́klady odpovědí: „V práci se penize prostě vydělávaji." "Mamka si je nosi z práce." „Dostávají je v práci. Někteři lidé ještě mohou penize padèlat nebo ukrást."

vzhledem k malé ochotě žáků zabývat se otázkou dále se nám nepodařilo o jejich pojetí zjistit víc. Odpovědi této skupiny jsme parafrázovali: zdrojem peněz je „práce“ sama o sobě. Pojem „práce“ zde označuje instituci, nikoli proces, proto jej uvádíme v uvozovkách.

\section{B - Jednosměrný pohyb peněz z banky - zásobování penězi}

$\mathrm{Na}$ otázku po zdroji peněz rodiny šest dotazovaných uvedlo původ peněz pouze a prýmo v bance. Do své odpovědi ani po následných otázkách nezahrnuli zdůvodnění, proč banka rodičům peníze posílá, neuvedli ani žádnou další instituci, která by měla na výplatu rodičům vliv.

Př́klady odpovědí této skupiny: „Máme je z banky, kde si ty penize vyrábèj, tak tam se taky poŕizujou. Vždycky zavoláme tý bance, jestli nám daj takovej počet, kterej můžou. Třeba 500." „Do banky dal penize výrobce peněz, aby byly $v$ bance $v$ bezpeči.“" „Penize se tisknou v tiskárnè, někdo je vytiskne a pak je rozdává." „Z karty, ta pani to tam naúctuje a vytiskne."
Pro tuto skupinu žáků je zdrojem peněz pouze banka, která je sama vyrábí nebo dováží z tiskárny, uvedený typ odpovědí jsme parafrázovali jako zásobování penězi.

\section{C - Jednosměrný pohyb peněz po hierarchii - platí autority}

Představu jednosměrného toku peněz od banky směrem $\mathrm{k}$ rodičům indikuje i dalších šestnáct odpovědi, ale na rozdíl od předchozích naznačují určitý vztah mezi výplatou peněz a prací rodičů. K nejjednoduššímu pojetí z uvedeného počtu odkazuje sedm odpovědí, jež jako zdroj peněz pro rodinu uvádějí „šéfa“, který rodičům platí: „Ta firma, která vyrábi penize, je dává do té práce, aby je mohli dávat tèm zaměstnavatelìm." "Pracuje, bývá $v$ práci dlouho a za to dostává víc penèz. Platí mu séf."

Hierarchicky složitější uspořádání jsme identifikovali u dalších devíti dotazovaných: "Máma je má od vrchni, ta je má od šéfky v̌̌eho - ředitelky. "Při dalších otázkách na původ peněz dotazovaná odpovídá: „Ředitelka je vybere v bance, penize do bank rozesilá stát, tiskne je."

Podobnou představu, kdy hlavní roli hraje nadř́izený, indikuje odpověd' na upřesňující otázku: "Za co maminka v práci penize dostává?" - „Dostane je od šéfa. Jeji šéf je má z ministerstva práce“. "Banka je má z ministerstva financí."

$\mathrm{V}$ odpovědích žáků se nepodařilo identifikovat ekonomická kritéria, podle kterých jsou rodiče placeni. Absence ekonomických zdůvodnění výše př́ijmu naznačuje spíše než specifickou představu 
ekonomického fungování použití obecné představy hierarchického uspořádání, kdy nadřízení hrají roli autority, která řídí a odměňuje podle bliže nespecifikovaných kritérií. Toto pojetí bylo u žáků mladšího školního věku zjišstěno opakovaně a bývá dáváno do souvislosti s jejich vlastní zkušeností s autoritou (Berti \& Bombi, 2002).

Vzhledem k náznaku jisté struktury společnosti jsme toto pojetí vyhodnotili jako rozvinutější. Parafráze odpovědí $\mathrm{v}$ této kategorii je: platí autority.

$\mathrm{Z}$ představy hierarchického upořádání vycházela i část odpovědí na otázku po původu peněz v bankách. Respondenti odpovídali, že peníze do bank posílá vláda nebo stát, který je vyrábí nebo má. Ale ani zde nebyla detekována představa omezenosti zdrojů a kritérií jejich rozdělování.

\section{D - Zapojení do obchodování - oběh peněz}

Za nejvíce rozvinuté považujeme odpovědi kategorie $\mathrm{D}$, do které jsme zařadili 10 odpovědí reflektujících oběh peněz a systém vztahů, ve kterém někteří vyrábejjí a prodávají a jiní nakupují. Ze čtyř kategorií pouze tato indikuje představu specificky ekonomického fungování společnosti.

$\mathrm{Z}$ této skupiny šest dotazovaných uvedlo, že rodiče nabízejí svou službu, všichni to vysvětlují na př́kladu práce svých rodičů živnostníků nebo zaměstnanců soukromých firem: „Táta má firmu na nábytek, prodávaji rüzný vèci. A ostatni lidi jim platí." "Přesnè nevím, kupuje někde vina a někam je vozi a pak je prodává."
Podobný typ odpovědí podali další čtyři respondenti, když byli dotazováni na původ peněz ve firmách: „Maji je od šéfa. Ten je ziská za to, co ty jeho jakoby služebnici udělají. Ten to někam pošle a oni mu za to daji penize."

Představu oběhu peněz jsme identifikovali také $\mathrm{v}$ odpovědích na otázku po původu peněz $\mathrm{v}$ bankách, kdy devět dotazovaných uvedlo, že do bank si ukládají peníze lidé: „Jo, vlastně, my si je vyděláme a dáme si je do banky. A potom si tam zajdeme." „Od vlády, ta je tam dává. Taky lidi je tam můžou dávat. ",Penize v bance se berou z karty. Člověk si nechá odečist penize $z$ karty a do banky je dávaji lidé."

Představu oběhu identifikujeme také v odpovědi, která uvádí zdroj peněz pro rodinu podobně jako dotazovaní z předchozí kategorie: „Máma má penize z banky, kam ji je pošle táta, táta je dostane $z$ radnice. Radnice má penize z ministerstva školstvi. Ministerstvo má penize z nejvètši banky $v$ Praze. "Na dotaz po původu peněz v bankách ale uvádí: „Banky maji penize $z$ dani a z peněz od výrobcü.

Tato odpověd' je jedinou, která naznačuje způsob financování ve státním sektoru. Opět je tu důležitou podmínkou zkušenost žáka s prací rodičů.

Odpovědi $\mathrm{v}$ této kategorii byly parafrázovány jako oběh peněz při obchodování.

$\mathrm{Na}$ odpovědích zařazených do kategorií A-C, které indikovaly představu jednosměrného pohybu peněz od institucí $\mathrm{k}$ rodičům, se rovnoměrně podílely věkové skupiny respondentů do $10 \mathrm{i}$ nad 10 let. $\mathrm{Z}$ odpovědí zařazených do kategorie $\mathrm{D}$, 
jež naznačovala představu obousměrného oběhu peněz, byly čtyři odpovědi od respondentů mladších 10 let a dvě od žáků starších 10 let.

\subsection{Zdůvodnění výše výdělku u profesí}

Kvůli četnosti odpovědí odkazujících na představu, že rodič musí být v práci, aby dostal peníze, jsme se v doplňujícím dotazování zaměřili prímo na příklady profesí, které jsou dobře a které naopak špatně placené. $\mathrm{V}$ centru naší pozornosti byla zdůvodnění jejich představ, konkrétně uvedení faktorů, které výši platů ovlivňují.

\section{Důvody vysokého výdělku}

20 respondentů uvedlo celkem 34 důvodů, proč mají někteří lidé vysoké př́ijmy.

Náznak představy o původu výdělku ve spojitosti s trhem práce (služeb) je možné vidět ve 12 odpovědích, které jsme označili kódy velká poptávka, obchodování a speciálni dovednosti, odpovědi indikují představu žádaných služeb, za které jsou lidé ochotní platit, protože je chtějí nebo potřebují. Tuto skupinu odpovědí jsme nazvali poptávka.

Další skupina 13 odpovědí označených kódy zásluha, prospěšnost, ale také nepoctivost ukazuje na způsob posuzování, kdy si vysoký výdělek lidé zasluhují tehdy, když jsou prospěšní druhým, hodně pracují, nebo mají vysoký výdělek nezaslouženě, když jsou nepoctiví. Skupinu jsme nazvali zásluhy.

Dalších devět odpovědí odkazuje $\mathrm{k}$ představě, že lidé slavní a významní mají vysoké př́ijmy. Bezprostředním důvodem vysokých př́ijmů je zde právě sláva nebo oblíbenost Jedná se spíše o konstatování než zdůvodňování vysokých příjmů nebo posouzení jejich oprávněnosti. Kategorii jsme nazvali popularita.

\section{Důvody nízkého výdělku}

Otázka na důvody nízkého výdělku byla pro respondenty obtížnější, při dotazování 20 respondentů se čtyřikrát objevila odpověd' nevím, u zdůvodňování nízkých výdělků jsme získali 16 možností, které jsme kódovali a dále kategorizovali.

Odpovědi typu „umí to, co každý“", „lidé za takovou práci neplatí mnoho“, „nemůže sehnat práci“ podle našeho názoru předpokládá představu trhu, kde lidé nabízejí své dovednosti, po kterých je nebo není poptávka, príklady odpovědí jsou v tabulce 1 . Uvedená zdůvodnění př́ijmů předpokládají existenci nabídky a poptávky, jedná se o osm odpovědí, které řadíme ke kategorii poptávka.

Odpovědi jako „pracují málo“, „ je to lehká práce“, „je to nepotřebná práce“ vypovídají o posuzování zásluh a společenské významnosti profese. Jako nepotřebnou práci hodnotili dotazovaní např́klad úklid a práci s odpadky, prŕklady uvádí tabulka 2. Těchto sedm odpovědí jsme prriřadili do kategorie zásluhy.

V kategorii popularita žáci uváděli mimořádně dobře placené profese $\mathrm{z}$ oblasti sportu a showbyznysu, vybrané příklady jsou $\mathrm{v}$ tabulce 3. Zařadili jsme sem také jednu odpověd', která zdůvodňovala nízké př́ijmy neoblíbeností. 
Dotazovaný takto hodnotil učitelskou profesi.

U důvodů vysokých i nízkých přijmů profesí můžeme tedy sledovat tř̌i společné kategorie, pro větší přehlednost je spolu $s$ ukázkami odpovědí prezentujeme $\mathrm{v}$ tabulkách 1-3.

\section{SHRNUTí}

$\mathrm{Z}$ odpovědí na otázky $\mathrm{k}$ faktorům ovlivňujícím výši mzdy, se můžeme domnívat, že většina respondentů $s$ určitou představou mechanismu, který peníze distribuuje, pracuje. Ale pouze menší část

Tab. 1. Výše výdělku na základě poptávky

\begin{tabular}{|c|c|}
\hline Vysoké př́ijmy - 12 odpovědí & Nízké příjmy - 9 odpovědí \\
\hline $\begin{array}{c}\text { "Zubaři, protože hodně lidí potřebuje spravit } \\
\text { zuby.“" }\end{array}$ & $\begin{array}{c}\text { "Uklízečka, protože na to nemusí mít žádnou } \\
\text { školu.“ }\end{array}$ \\
\hline „Něco u počítače, to lidi hodně chtěj." & „Popeláři, protože to může dělat každý.“ \\
\hline $\begin{array}{l}\text { "Podnikáním, když prodávaj to, co se hodně } \\
\text { prodává." }\end{array}$ & $\begin{array}{l}\text { „Popeláŕi, protože to lidi nepotřebují.“ } \\
\text { „Uklízení, protože je to nepotřebná práce.“ }\end{array}$ \\
\hline „Doktor, protože je hodně nemocných.“ & $\begin{array}{c}\text { „Popeláři a ti, co napichují odpadky, protože } \\
\text { tahle práce se moc neplatí." }\end{array}$ \\
\hline
\end{tabular}

Tab. 2. Výše výdělku na základě zásluh

\begin{tabular}{|c|c|}
\hline Vysoké př́ijmy - 13 odpovědí & Nízké př́ijmy -7 odpovědí \\
\hline „Doktor, protože pomáhá lidem.“ & „Uklízeči, protože je to lehká práce.“ \\
\hline „Sestřička, je to těžká práce.“ & $\begin{array}{c}\text { „Popeláři, mají lehkou práci, vyvážejí jenom } \\
\text { odpadky." }\end{array}$ \\
\hline „Jako prezident, protože vládne celé republice.“ & $\begin{array}{c}\text { „Když pracují málo. Protože když pracují málo, } \\
\text { tak udělají málo práce, tak nemǔžou dostat } \\
\text { moc peněz." }\end{array}$ \\
\hline $\begin{array}{l}\text { „Hodně peněz si vydělávají třeba sportovci, } \\
\text { třeba hokejisti. Když jsou úspěšný, dostávají } \\
\text { odměny.“ }\end{array}$ & \\
\hline
\end{tabular}

Tab. 3. Výše výdělku na základě popularity

\begin{tabular}{|c|c|}
\hline Vysoké prŕijmy -9 odpovědí & Nízké př́ijmy - 1 odpověd' \\
\hline $\begin{array}{c}\text { "Jako zpěvák nebo fotbalista. Protože je slavnej.““ } \\
\text { „lavní lidé mají hodně peněz, lidi z televize.“ }\end{array}$ & "Učitelky, protože učitelky nejsou oblíbené.“ \\
\hline $\begin{array}{c}\text { „Herectvím, hraje ve filmech a filmy mají lidé } \\
\text { rádi.“ }\end{array}$ & \\
\hline
\end{tabular}


odpovědí odkazovala přímo $\mathrm{k}$ trhu práce. Tyto odpovědi jsme přiřadili ke kategorii poptávka, odpovědi zde výši výdělků zdůvodňují schopnostmi, které pracující nabízí, př́ípadně jejich absencí nebo poptávkou po jejich službách a ochotou za ně platit. Kategorie zásluhy a popularita neodkazují k ekonomickému zdůvodnění příjmů, sdružují obecná vysvětlení, která vycházejí spišse ze sociální zkušenosti žáků.

\section{DiSKUSE}

Při srovnání výsledků s dosavadními výzkumy, můžeme konstatovat, že v našem výzkumu se na jednotlivých kategoriích odpovědí podíleli rovnoměrně žáci z obou věkových skupin. Oproti výsledkům Bertiové et al. (1988), kde hlavním faktorem ovlivňujícím rozvinutost pojetí byl věk, se nám jeví jako významněǰsí činitel zkušenost žáků se zaměstnáním rodičů. Toto zjištění je blíže k výsledkům Webleyho (2004) a Leisera et al. (1990), kteří při hledání faktorů ovlivňujících pojetí dotazovaných žáků považují za významný sociální kontext a vlastní zkušenosti oproti čistě vývojovému hledisku.

Většina dotazovaných neuváděla v rozhovorech konkrétní výkon práce rodičů, nezmiňovala důvody odměňování ani původ peněz u zaměstnavatele. Tito žáci se omezili na obecný popis odměňování autoritou nebo na popis výměny: prítomnost $\mathrm{v}$ práci za vyplácení peněz pro rodinu. Toto pojetí považujeme za blízké zjištěním Leisera et al. (1990) a Webleyho
(2004) - jde o pojetí firem jako institucí sociálního zabezpečení.

Leiser et al. (1990) uvádí, že respondenti, kteří tímto způsobem nahlíželi na fungování firem, již nepoukazovali na žádné další ekonomické souvislosti a propojení institucí. $V$ odpovědích našich respondentů byly i při méně rozvinutém pojetí pravidelně zmiňovány banky jako instituce, které vyrábějí peníze a firmy i jednotlivce jimi zásobují. Je otázkou, jestli můžeme tuto představu považovat za komplexnějš́í, protože banky zde často reprezentovaly pouze zdroj peněz nebo instituci, která peníze distribuuje.

Ke zjištěním o komplexnosti pojetí respondentů považujeme za důležité reflektovat kontext otázek a úloh, ze kterého se v rozhovorech vycházelo (Clement, 2000). Ve snaze vyjít vstřríc respondentům bylo v zadání úloh předloženo stanovisko jednotlivce, které leží pevněji v jejich vlastní zkušenosti, např́klad otázka na zdroj peněz $\mathrm{v}$ rodině. Je možné, že nabídnuté stanovisko individuálního účastníka mohlo ovlivnit míru obecnosti odpovědí.

Přes omezenou výpovědní hodnotu této studie považujeme za zajímavé porovnání našich výsledků se starší srovnávací studií (Vyskočilová \& Morgado, 2000). $\mathrm{V}$ této studii porovnání výsledků žáků z ČR a Portugalska ukázalo na významněǰsí vnímání role státu v pojetích z České republiky. Stejně tak oproti výsledkům dalších srovnávacích studií (např. Berti \& Bombi, 1988; Jahoda, 1983) podle Vyskočilové (Vyskočilová \& Morgado, 2000) české děti méně často odkazovaly na původ peněz od šéfa, ale častěji uváděly jako 
jejich zdroj prímo stát. $V$ našem šetření jsme u dětí významněji vnímanou roli státu v oběhu peněz nezaznamenali. Přestože náš výzkum nepodává reprezentativní výsledky a jeho cílem ani nebylo potvrzovat nebo vyvracet zjištění předchozích výzkumů, domníváme se, že indikované tendence $\mathrm{v}$ porozumění oběhu peněz nebyly výrazně odlišné od respondentů ze států $s$ tradičně fungujícím volným trhem. Závislost na autoritách nejspíš nemůžeme vysvětlovat historickou zkušeností, ale opět osobní zkušeností života dítěte pod ochranou autorit.

Při hodnocení výsledků $\mathrm{v}$ rovině obecně didaktické chceme přispět do diskuse o podobě dětských pojetí v rámci teorie konceptuální změny. $\mathrm{V}$ tematické části výzkumu zaměřené na zdroj peněz pro rodinu kategorizujeme odpovědi podle míry jejich elaborovanosti, komplexnosti. Odpovědi $\mathrm{v}$ kategoriích $\mathrm{A}-\mathrm{C}$ indikují představu jednosměrného pohybu peněz. $V$ těchto rozhovorech se nepodařilo detekovat struktury, které by bylo možné nazvat „teorií", tak aby vysvětlovala fungování celého systému. Existenci vlastní teorie, jak ji chápe teorie konceptuální změny (Vosniadou, 2013), vykazovaly pouze odpovědi $\mathrm{v}$ kategorii $\mathrm{D}$ nazvané oběh peněz. $V$ tematické části zaměřené na zdůvodnění výše výdělku byla u většiny dotazovaných zjištěna představa mechanismu, který peníze distribuuje, ale pouze odpovědi $v$ jedné ze tří kategorií nazvané poptávka dávají vysvětlení, které je koherentní. $V$ tomto př́padě vysvětlují fungování trhu práce na zá- kladě nabídky a poptávky. Celkově naše závěry odpovídají spíše pojetí fragmentů systému s tím, že jednotlivé jeho části navzájem koherentní nejsou (di Sessa, 2013).

\section{ZÁVĚR}

Domníváme se, že elicitované představy dětí o oběhu peněz mohou přispět oborové didaktice společenských věd jako východisko pro proces konceptuální změny, zejména $\mathrm{v}$ pojetí Chiové (2013), která nabízí přístupy pro iniciaci konceptuální změny podle povahy dětských pojetí. Jedná se o popsané varianty neúplných, chybných konceptů nebo o absenci konceptů, kdy práce učitele podle Chiové (tamtéž) spočívá v doplňování mezer pojetí a následně ve vyvolání kognitivního konfliktu. Inspirací pro konkrétní výukové postupy mohou být Parsonsovy návrhy založené na metodách sociálního učení (Parsons \& Mamo, 2017).

V obou částech výzkumu je zřejmé, že žáci mají tendenci aplikovat na ekonomickou sféru vlastní sociální zkušenost. Dochází pak k tomu, že místo ekonomických kritérií posuzují situace na základě kritérií morálních.

Zde vidíme př́ležitost pro výuku, která prostřednictvím práce $s$ konkrétními situacemi nakupování, placení aj. může u žáků rozvíjet oborově specifické porozumění. Návrh možností intervencí pro iniciaci konceptuální změny je nad rámec této studie, ale domníváme se, že jisté podněty zde představeny byly. 


\section{LiterATURA}

Barrett, M., \& Buchanan-Barrow, E. (2004). Children's understanding of society. Hove: Psychology Press.

Bastounis, M., Leiser, D., \& Roland-Levy, C. (2004). Psychosocial variables involved in the construction of lay thinking about the economy: Results of a cross-national survey. Journal of Economic Psychology, 25, 263-278.

Berti, A. E. (2002). Children's understanding of society: Psychological studies and their educational implications. In E. Nasman \& A. Ross (Eds.), Children's understanding in the new Europe (s. 89-107). Trentham Books.

Berti, A. E., Bombi, A. S., \& Duveen, G. T. (1988). The child's construction of economics. Cambridge: Cambridge University Press.

Bonn, M., \& Webley, P. (2000). South African children's understanding of money and banking. British Journal of Developmental Psychology, 18(2), 269-278.

Brophy, J., Alleman, J., \& Halvorsen, A. (2018). Powerful social studies for elementary students. 4. vyd. Belmont, CA: Cengage.

Carey, S. (1988). Conceptual differences between children and adults. Mind \& Langugage, 3(3), $167-181$.

Clement, J. (2000). Analysis of clinical interviews: Foundations and model viability. In R. Lesh \& A. Kelly (Eds.), Handbook of research methodologies for science and mathematics education (s. 341-385). Hillsdale: Lawrence Erlbaum.

Davies, P. (2019). The construction of frameworks in learners' thinking: Conceptual change and threshold concepts in economics. International Review of Economics Education, 30, 100-135.

di Sessa, A. A. (2013). A bird's-eye view of the „Pieces“ vs „Coherence“ controversy. In S. Vosniadou (Ed.), International handbook of research on conceptual change (s. 31-49). New York: Routledge.

Doulík, P. (2005). Geneze dètských pojetí vybraných fenoménů. Ústí nad Labem: Univerzita J. E. Purkyně. Hesová, A. et al. (2014). Katalog materiálů pro rozvoj finančni gramotnosti. Praha: Národní ústav pro vzdělávání. Dostupné z http://clanky.rvp.cz

Hradil, D. (2012). Shrnutí hlavnich výstupì z mèreni finančni gramotnosti obyvatel ČR pro $M F$ a ČNB. Dostupné z www.mfcr.cz

Hutchings, M. (2002). Toward an antidevelopmental view of children's social and economic inderstanding. In E. Nasman \& A. Ross (Eds.), Children's understanding in the new Europe (s. 32-60). Trentham Books.

Chi, M. T. H. (2008). Three types of conceptual change: Belief revision, mental model transformation, and categorical shift. In S. Vosniadou (Ed.), International handbook of research on conceptual change (s. 61-82). New York: Routledge.

Chi, M. T. H. (2013). Two kinds and four sub-types of misconceived knowledge, ways to change it, and learning outcomes. In S. Vosniadou (Ed.), International handbook of research on conceptual change (s. 49-71). New York: Routledge. 
Jahoda, G. (1983). European "lag“ in the development of an economic concept: A study in Zimbabwe. British Journal of Developmental Psychology, 1, 113-120.

Janík, T. et al. (2007). Pedagogical content knowledge nebo didaktická znalost obsahu? Brno: Paido. Jelemenska, P., Sander, E., \& Kattmann, U. (2003). Model didaktickej rekonštrukcie: Impulz pre výskum v oborových didaktikách. Pedagogika, 53(2), 190-201.

Klínský, P., \& Chromá, D. (2009). Finanční gramotnost: úlohy a metodika. Praha: Národní ústav odborného vzdělávání.

Leiser, D., \& Drori, S. (2005). Naive understanding of inflation. The Journal of Socio-Economics, 34, 179-198.

Leiser, D., \& Halachmi, R. B. (2006). Children's understanding of market forces. Journal of Economic Psychology, 27(1), 6-19.

Leiser, D., Seven, G., \& Daphna, L. (1990). Children's economic socialization: summarizing the cross-cultural comparison of ten countries. Journal of Economic Psychology, 11, 591-614.

Marton, F., \& Pang, M. F. (2008). The idea of phenomenography and the pedagogy of conceptual change. In S. Vosniadou (Ed.), International handbook of research on conceptual change (s. 533-559). New York: Routledge.

Özdemir, G., \& Clark, D. B. (2007). An overview of conceptual change theories. Eurasia Journal of Mathematics, Science and Technology Education, 3(4), 351-361.

Parsons, R., \& Mamo, M. (2017). The source and impact of student preconceptions in economics principles classes. International Review of Economics Education, 25, 15-24.

Siegler, R. S., \& Thompson, D. R. (1998). Hey, would you like a nice cold cup of lemonade on this day? Children's understanding of economic causation. Developmental Psychology, 34(1), $146-160$.

Škoda, J. (2005). Současné trendy v prírodovédném vzděláváni. Ústí nad Labem: Univerzita J. E. Purkyně.

Vosniadou, S. (Ed.). (2008). International handbook of research on conceptual change. New York: Routledge.

Vosniadou, S. (Ed.). (2013). International handbook of research on conceptual change. 2. vyd. New York: Routledge.

Vyskočilová, E., \& Morgado, L. (2000). Rozumí české děti ekonomickým pojmům a vztahům podobně jako portugalské děti? Československá psychologie, 44(6), 528-537.

Webley, P. (2004). Children's understanding of economics. In M. Barrett \& E. Buchanan-Barrow (Eds.), Children's understanding of society (s. 43-67). Hove: Psychology Press.

Ing. Michaela Dvoráková, Ph.D.

Univerzita Karlova, Pedagogická fakulta, katedra občanské výchovy a filozofie;

e-mail: michaela.dvorakova@pedf.cuni.cz 


\section{DVOŘÁKOVÁ, M. Children's Understanding Economic Relations: Primary school pupils' conceptualisation of the circulation of money}

The study introduces the issue of the development of children's understanding of economic relations in the period of primary education. In-depth interviews focused on ways of raising money for the family's livelihood investigate children's justifications for different income levels and, more generally, the concept of the circulation of money. It compares the results with similarly focused foreign research from the last 30 years.

Goals: The concepts of partial phenomena of economic life that were identified indicate tendencies in the thinking of primary school pupils and offer starting points for the teaching of primary social science.

Method: Data from semi-structured interviews was processed. The transcripts of the interviews were coded and the children's concepts were subsequently categorised according to the degree of their complexity and the compatibility of partial ideas.

Results: In both parts of the research, children's concepts show a tendency to apply their own social experience to the economic sphere. Domain-specific concepts referring to the idea of the labour market or the circulation of money in society were connected to the pupils experience with the employment of parents or to other specific examples more than the development period.

Conclusion: The views of the labour market and the circulation of money that were elicited can contribute to the didactics of social sciences as a starting point for the process of conceptual change. The results offer variants of incomplete, misconceptions and provide stimuli for the initiation of conceptual change in teaching.

Keywords: children's understanding, conceptual change, semi-structured interview, primary education, circulation of money, financial literacy 